\title{
Reflections on a footnote: implications for the study of emotions in animals ${ }^{1}$
}

\author{
Emma Otta* \\ Universidade de São Paulo, Instituto de Psicologia, Departamento de Psicologia Experimental. São Paulo, SP, Brasil
}

\begin{abstract}
A footnote (FN) originally submitted as a comment to the article "Parsing Reward" led me to write this essay. The comment was rejected by the editor of a prestigious scientific journal in the area of behavioral neuroscience with the suggestion that it would be more appropriate for an "idle talk". I believe that the core issues involved are important to address explicitly in a debate within the broad domain of the frontiers of human and biological sciences. The protagonists involved in the didactic episode of the $\mathrm{FN}$, whose articles and books I have been reading over the years, are leaders in the field of neuroscience. In this essay the episode is historically contextualized and discussed in terms of potential implications for ethology, psychology and neuroscience.
\end{abstract}

Keywords: emotion, animals, ethology, psychology, neuroscience.

A footnote added to the article "Affective consciousness: Core emotional feelings in animals and humans", published in the journal Consciousness and Cognition (Panksepp, 2005), led me to write this essay in order to discuss the study of emotions in animals and implications of this type of research for understanding human psychological processes.

The text of the Footnote (FN) was originally submitted by Jaak Panksepp to the editor of Trends in Neuroscience as a comment to the article "Parsing reward" (Berridge \& Robinson, 2003) immediately after it was published. However, the text was refused for publication, and the ideas were disqualified as more appropriate for an "idle talk". In my point of view, the FN provides important ideas for our reflection, and should not be sent to an "inactive file". "Idle talks" may promote lateral thinking, and creative ideas arise in informal conversations among scientists. Such ideas may later be developed as experiments in the sober environment of research laboratories, and result in articles accepted for publication. However, I believe that a debate on this FN (reproduced further in this article) deserves to be brought to a journal such as Psicologia USP [USP Psychology], which has a leadership role in the academic scenario of Brazilian psychology, publishing significant debates in areas of frontier of human and biological sciences. I hesitated to write this essay for several reasons, including the fact that the episode occurred a few years

1 I thank Prof. Nicolas Gérard Chaline, from the Department of Experimental Psychology of the Institute of Psychology of the University of São Paulo, for the French version of the article abstract; Prof. Andrés Eduardo Aguirre Antúnez, from the Department of Clinical Psychology, for the Spanish version; and Prof. Russell David Hamer of the Department of Psychology at Florida Atlantic University, for the revision of the abstract in English.

* Correspondent author: emmaotta@gmail.com ago, but I decided to write it because I believe that the involved core issues are important and remain current.

\section{The suggestive Footnote}

My reading of this paper was that the authors advocated the position that animals exhibit only affective behaviors, whereas humans have true affective experiences because of their cortical enrichments. Within a few days of publication of the piece of Berridge and Robinson, I submitted the following letter (references deleted) as a letter to the editor. The authors declined to respond (I assume because taking a position on such topics can leave you branded with the Scarlet letter of Anthropomorphism), and the editor wrote back about half a year later: "Please accept my sincere apologies... for your monumental patience... I do not feel that a letter exchange in TINS is the right place for expression of your ideas... I think that your ideas on this matter need to be raised in the discussion section after a relevant conference talk or in the bar."

Berridge and Robinson's reconceptualization of dopamine-facilitated "brain reward" into wanting (unconscious desire?) vs. liking has been a welcomed meme. It corresponds to classic appetitive approach and consummatory reward concept long accepted by psychologists, including sensory-perceptual biasing and cognitive linkages. A complementary solution to paradoxes associated with brain stimulation reward was the conceptualization of a dopamine driven appetitive SEEKING/expectancy emotional system - a "goad without a goal" that energizes foraging and mediates anticipatory states. Such emotional/motivational urges have many attributes, including sensory-perceptual biasing and cognitive linkages. Incentive salience may reflect conditioned cues getting easily into both the emotional action and the cognitive channel-control components of this widespread instinctual-emotional-learning 
system. Comparable emotional action systems are critical for diverse states of feelings that help to clarify the multidimensional concepts of reward and punishment, which encapsulate our meager understanding of the intrinsic value structures of the brain. To properly clarify affects, we must psychobiologically study many emotions and sensory rewards, as well as bodily regulatory/motivational urges (e.g., thirst and hunger). Affective feelings in animals - issues that B\&R have strategically, perhaps neo-dualistically, minimized - are likely to be true aspects of animate nature. An ontological key question, finally neuro-epistemologically workable, is the extent to which arousal of core emotional systems, like the SEEKING/Wanting system, is experienced in humans and other animals. Since Freud, it has been increasingly recognized that felt experience stews within an enormous unconscious neural caldron. However, is it culturally and scientifically wise for us to deny, ignore or minimize the probable existence of neuroaffective states in other mammals when so much evidence suggests that they have such experiences? All humans affirm that affective experiences are critical for the quality of life. Considering the weight of relevant evidence, there is no principled reason (only our desire for proof - which does not exist in science) to marginalize affective experience in the neuro-mental lives of animals. Considering the abundant data from bodily expressive, place-preference, and vocal measures, a scientifically coherent working hypothesis, quite capable of generating testable predictions, is that other mammals do have affective feelings functionally similar to our own. Even though we have no access to the precise nature of their associated cognitions and qualia, for optimal progress, it is reasonable to entertain a role for neuroaffective core processes for scientifically understanding what animals do. If basic affects arise largely from evolutionarily conserved core neurodynamics in all mammals, we can finally fathom the nature of homologous value structures that move humans. This critically important step may allow us to better conceptualize brain-mind imbalances in psychiatric disorders. Concepts like SEEKING/wanting are promising starts, but let us not make subcortical affect-generating networks unconscious prematurely. The evidence for that remains weak. In fact, studies like that of Lamb and colleagues say little about unconscious motivations. Why reaffirm, even implicitly, the Cartesian sin of granting so little experienced life to other animals? Abundant evidence indicates that raw affective experiences are critically linked to the neurodynamics of sub-neocortical limbic networks (homologous in all mammals), and not to neocortical re-representations that abundantly regulate and refine emotions. At what level of the neuroaxis do the deeply unconscious aspects of many brain functions blend with those that are experienced? We do not know. Affectively, the neocortex may be more unconscious than sub-neocortical limbic regions. As essential as learning is for navigating complex environments, well conceptualized by $B \& R$, it is unparsimonious to speculate that core values are only experienced when read out by higher cognitions. Despite our disciplinary aversion to spooky neuropsychological constructs, feelings may arise more directly from brain emotional, motivational, and sensory systems in action, even in rats. Finally, it should be noted that psychological processes may emerge as much from motor-action processes (SEEKING) as from sensorycognitive processes (wanting and liking) ${ }^{2}$.

\section{Current scenario and historical background}

The protagonists involved in the didactic episode of the FN, whose articles and books I have been reading over the years, are leaders in the field of neuroscience. But regardless of who is involved, what is interesting for us is to contextualize the episode and to think about it in terms of potential prospects.

Ethology has a history of research on communication and expression of emotion in animals, inspired by Charles Darwin's (1872/2000) classic “The expression of the emotions in man and animals." However, it is notable that many ethologists have difficulty in answering the questions: "Do animals experience emotions?", "Does your research animal has emotions?". I interpret this difficulty as a result of specialization of the area. As a result of its development over the past decades, ethology has become increasingly specialized. Among the new specialties that emerged are behavioral ecology, behavioral genetics, neuroethology, animal cognition, applied ethology, human ethology and evolutionary psychology. Factual and theoretical progress has been made in each of these new specialties. However, there was also a reduction of communication among specialties. The history of science is replete with examples of controversies due to the difficulty of a group of scientists to understand the terms and concepts that another group uses. During his stay at the Institute for Advanced Studies at the University of São Paulo in 2013 and 2014, Jerry Hogan, Emeritus Professor of the Department of Psychology, University of Toronto, was writing the book "The study of behavior", aimed to provide a theoretical framework for studying human and animal behavior which integrates concepts and results of the various areas of ethology. Texts that contribute to increase the communication among scientists from various specialties, favoring new insights as a result of this facilitated communication, are needed. It was also with this objective that we organized, in 2013, the XXXI Annual Meeting of Ethology, whose theme was "The Founding of Brazilian Ethology and Future Prospects", honoring Professor Walter Hugo Cunha de Andrade, founder of Ethology in Brazil, as part of an effort to recover our history and reflect on the future. This was also the motivation that led me to write this essay.

While writing, I remembered that a classic article of the pioneer of Brazilian ethology was rejected for publication

2 References deleted from the mentioned letter; they are available on request. Panksepp (2005) 
by the editors of Insectes Sociaux. At the invitation of Cesar Ades, the text was published in Revista de Etologia. It was republished as part of Lessons from Alameda Glete: collection of texts by Walter Hugo Cunha, pioneer of ethology in Brazil (Otta, Ribeiro \& Bussab, 2013). In the chapter "The originality of Walter Hugo de Andrade Cunha: spontaneous generation", Fernando Ribeiro describes what happened:

He sent an article with some of his findings ... to the journal Insectes Sociaux. The article was rejected because one of the referees did not understand what he read. The alarm pheromones and marked trails were important discoveries and they were in vogue. They are social features, communication tools. Using the alarm pheromone, the ant sends a signal that can trigger panic responses and disrupt their conspecifics' behavior. But Walter Hugo's article went far beyond this simple statement. Furthermore, it originally suggests the creation of a taxonomy for panic reactions. So, sadly, a crucial milestone of the nascent Brazilian Ethology had its publication rejected ... in 1974. The article was entitled 'On the panic reactions of ants to a nestmate crushed: a Contribution to the psychoethology of fear.' I suppose that the title, referring to a psychoethology, 'the psychoethology', may have caused a panic reaction in the journal's referee, as this term was also new, almost unprecedented. In 2004, Cesar Ades took the valuable initiative to publish the article in the Brazilian journal Revista de Etologia. (pp. 133-140)

Behaviorism has a history of disregarding the study of emotions. Burrhus Frederic Skinner (1953) once stated, "The 'emotions' are excellent examples of the fictional causes to which we commonly attribute behavior" (p. 160). Psychology should concern with the observable behavior of people and animals, not with unobservable events that take place in their minds. Any explanation of the behavior of organisms should be sought in the environment, based on general learning principles from the study of a small number of animal species, usually rats and pigeons in controlled laboratory studies. Little attention was given to differences among species (Beach, 1950). Evidence of instinctive drift, i.e., the tendency of an animal to revert to instinctive behaviors that interfered with a conditioned response, was generally ignored (Breland $\&$ Breland, 1961). The investigation of the intrinsic dynamics of the "black box" was considered unnecessary, and the study of its inputs and outputs was enough. There was little interaction between areas. When asked during his visit at USP: "Have you not read Tinbergen ${ }^{3}$ ?", Fred Keller ${ }^{4}$ answered with another question: "Who is Tinbergen? A poet?"

3 The ethologist Niko Tinbergen was one of the winners of the Nobel Prize in Physiology/Medicine in 1973 for his research on the organization and elicitation of individual and social behavior patterns in animals.

4 Interview with Professor Walter Hugo Cunha de Andrade made by Cesar Ades, Marina Massimi and Roberto de Andrade Martins in May 7
Box 1. In response to Jaak Panksepp's letter (1990, pp. 142-147) on September 7, 1987, Professor Skinner replied on September 22, 1987:

Dear Dr. Panksepp,

As I pointed out in a paper I gave at the recent meeting of the American Psychological Association, a behavioral account has two unavoidable gaps - between stimulus and response, and between reinforcement and a resulting change in behavior. Those gaps can be filled only with the instruments and techniques of neurology. A science of behavior need not wait until neurology has done so. A complete account is no doubt highly desirable but the neurology is not what the behavior really is; the two sciences deal with separate subject matters. A third discipline may very well wish to deal with how the two can be brought together, but that is not my field.

\section{Yours sincerely,} B. F. Skinner

The Figure 1, adapted from Panksepp (2011a), illustrates the answers that can be given to the question "Do animals have emotions?" and potential errors arising from these answers. Most of the twentieth century was spent believing the lower right quadrant would be the right place to be philosophically, avoiding type I errors, i.e., concluding that something exists when in fact it does not. Panksepp invites researchers to situate themselves in the upper left quadrant, thus avoiding type II errors, i.e., the inability to detect a real phenomenon, due to false beliefs or inadequate methods to assess its presence.

\begin{tabular}{|c|c|c|}
\hline & \multicolumn{2}{|c|}{ The true nature of the world } \\
\hline $\begin{array}{c}\text { Our judjements } \\
\text { about the world }\end{array}$ & $\begin{array}{c}\text { Animals } \\
\text { experience } \\
\text { emotional feelings }\end{array}$ & $\begin{array}{c}\text { Animals have } \\
\text { no emotional } \\
\text { feelings }\end{array}$ \\
\hline $\begin{array}{c}\text { Animals } \\
\text { experience } \\
\text { emotional feelings }\end{array}$ & $\begin{array}{c}\text { Valid } \\
\text { anthropomorfism }\end{array}$ & $\begin{array}{c}\text { Avoidance of } \\
\text { type I error }\end{array}$ \\
\hline $\begin{array}{c}\text { Animals have no } \\
\text { emotional feelings }\end{array}$ & $\begin{array}{c}\text { Avoidance of } \\
\text { type II error }\end{array}$ & $\begin{array}{c}\text { Valid } \\
\text { anthropodenial }\end{array}$ \\
\hline
\end{tabular}

Figure 1. Answers to the question "Do animals have emotions?" and potential errors associated with them. (Adapted from Panksepp, 2011)

I first became acquainted with the research work of Kent Berridge, coordinator of The Affective Neuroscience and Biopsychology Lab, Department of Psychology,

1990. Available at: http://www.cle.unicamp.br/arquivoshistoricos/Walter_Hugo/ewalter.pdf 
University of Michigan, in 2004, and since then I have been reading his publications (Berridge \& Kringelbach, 2010, 2011, 2013). When he published "Motivation concepts in behavioral neuroscience" (2004), we suggested the reading of this article to our undergraduate psychology students of the course "Motivation and Emotion" at the Institute of Psychology of the University of São Paulo. Cesar Ades and I talked about the resurgence of motivation as a significant issue for behavioral neuroscience. The article emphasizes the need for motivation concepts combined with behavioral neuroscience research to understand how the brain generates psychological processes and behavioral patterns helping neuroscience models to explain more than mere fragments of behavior.

There still remain today many contemporary counterparts to the behaviorist of the last century, in the form of neuroscience reductionists. Some of these reductionists still adhere to a basically logical positivist or extreme materialist conviction that all behavior must be explained without recourse to psychological levels of concepts and, instead, solely in terms of directly observed physical events: neurons, neuro-transmitters, etc. Such extreme reductionism is a vestige of 20th century positivist tendencies toward explanatory concreteness at all costs and, though now relatively rare, it has not yet disappeared. For modern reductionists, just as for traditional behaviorists, motivation is a difficult explanatory concept because it cannot be directly observed as a physical event. (p. 185)

Trying to explain how the brain controls motivated behavior without motivational concepts is like trying to understand what your computer does without concepts of software. Erich von Holst (1963), an important early behavioral neuroscientist, emphasized that we need what he called 'level-adequate' concepts to understand how brains control behavior. Level adequate means an explanation that adequately matches the level of complexity of the thing we are trying to explain. Concepts of hedonic reaction, incentive motivation, homeostatic reflex, hierarchy, heterarchy, etc., are all level adequate in the sense that they are the simplest possible concepts to adequately capture the crucial corresponding aspects of what brains actually do. (p. 205)

In The Affective Neuroscience and Biopsychology Lab research, studies on brain systems (hedonic hotspots) involved in the hedonic impact of a stimulus, such as sweet taste, and the incentive salience or motivational incentive value of the reward are conducted. There is a special interest in the analysis of reward in its specific psychological components: (1) learning (including implicit and explicit knowledge produced by associative conditioning and by cognitive processes); (2) affect or emotion (implicit "liking" and conscious pleasure) and (3) motivation (Incentive
Salience or cue-triggered "wanting" and cognitive incentives or explicit desires). The challenge is to identify how different brain circuits mediate different psychological components of reward, and how these components interact. There is interest in the potential applications of this research to drug addiction in humans, rational and irrational choices and conscious and unconscious emotion involved in everyday pleasures and desires ${ }^{5}$.

Figure 2, adapted from Berridge and Robinson's (2003) article "Parsing Reward" which triggered the episode of FN, distinguishes explicit and implicit dimensions of the psychological components of reward. The explicit aspects are consciously experienced as explicit desire, pleasure and hedonic expectation of reward, while the implicit aspects are unconscious, but can significantly influence behavior in the form of implicit incentive salience, "liking" and habits.

I first became acquainted with the research work of Jaak Panksepp, Professor Emeritus, Department of Psychology of Bowling Green State University and Washington State University, in 1998, and since then I have been reviewing his publications (e.g., Panksepp, 1992, 1998, 2004, 2005; Panksepp \& Biven, 2012). We suggested the reading of his books "Affective Neuroscience: The Foundations of Human and Animal Emotions" and "The Archaeology of Mind: Neuroevolutionary Origins of Human Emotions" to our undergraduate psychology students of the course "Motivation and Emotion" at the Institute of Psychology of the University of São Paulo, considering that it is in line with the psychoethological perspective of the course. Cesar and I talked about rats' "laughter" - fast $50 \mathrm{kHz}$ ultrasonic vocalizations $(<0.3-\mathrm{s})$ that the human ear cannot identify, but which can be recorded and submitted to spectrographic analysis - in positive affective circumstances such as rough-and-tumble play (Burgdorf et al, 2008; Knutson, Burgdorf \& Panksepp; 1998, 2002; Brudzynski \& Pniak, 2002), mating (Burgdorf et al., 2008), in response to drugs of abuse, e.g., amphetamine (Burgdorf et al., 2001; Thompson et al., 2006), and anticipation of rewards (Burgdorf, Knutson \& Panksepp, 2000). We also talked about rats' "whimper" - long 22 $\mathrm{kHz}$ ultrasonic vocalizations $(>0.3-\mathrm{s})$ - in negative emotional circumstances, such as an encounter with a predator (Blanchard, Blanchard, Agullana, \& Weiss, 1991), defeat by a conspecific (Thomas, Takahashi, Barfield, 1983; Tornatzky \& Miezek, 1994), withdrawal from drugs such as alcohol, benzodiazepines, opiates and psychostimulants (Covington \& Miczek, 2003; Ma et al., 2010; Vivian et al., 1994), and anticipation of aversive stimulation (Choi \& Brown, 2003; Lee, Choi, Kim \& Brown, 2001). The ultrasonic vocalizations of $50 \mathrm{kHz}$ express a positive, appetitive state and serve as a social affiliative signal, while the ultrasonic vocalizations of $22 \mathrm{kHz}$ express a negative, aversive state, and serve as an alarm signal (Brudzynski,

5 The interested reader can find representative articles and supplementary materials on the site http://www-personal.umich.edu/ berridge/ 


\begin{tabular}{|c|c|c|c|}
\hline Category & \multicolumn{2}{|c|}{$\begin{array}{l}\text { Psychological } \\
\text { Components }\end{array}$} & $\begin{array}{l}\text { Measurement } \\
\text { Examples }\end{array}$ \\
\hline \multirow[b]{2}{*}{ Motivation } & $\begin{array}{c}\text { Explicit } \\
\text { Dimension }\end{array}$ & $\begin{array}{l}\text { Cognitive Incentives } \\
\text { (Wanting) } \\
\text { Goal directed plans }\end{array}$ & $\begin{array}{l}\text { Subjective ratings } \\
\text { of desires }\end{array}$ \\
\hline & $\begin{array}{l}\text { Implicit } \\
\text { Dimension }\end{array}$ & $\begin{array}{c}\text { Incentive Salience } \\
\text { ("Wanting") } \\
\text { CS motivational } \\
\text { Magnet (“Wanting") } \\
\text { Cue trigered wanting }\end{array}$ & $\begin{array}{l}\text { Conditioned } \\
\text { approach }\end{array}$ \\
\hline \multirow{2}{*}{$\begin{array}{l}\text { Emotion or } \\
\text { Affect }\end{array}$} & $\begin{array}{c}\text { Explicit } \\
\text { Dimension }\end{array}$ & $\begin{array}{l}\text { Conscious Pleasure (Liking) } \\
\text { Explicit Hedonic Feelings }\end{array}$ & $\begin{array}{l}\text { Subjective ratings } \\
\text { of pleasure }\end{array}$ \\
\hline & $\begin{array}{l}\text { Implicit } \\
\text { Dimension }\end{array}$ & $\begin{array}{l}\text { Core Hedonic Impact } \\
\text { ("Liking") } \\
\text { Implicit Affect }\end{array}$ & $\begin{array}{l}\text { Facial Affective } \\
\text { Expressions }\end{array}$ \\
\hline \multirow{2}{*}{ Learning } & $\begin{array}{c}\text { Explicit } \\
\text { Dimension }\end{array}$ & $\begin{array}{c}\text { Cognitive } \\
\text { Reward Expectancy } \\
\text { Understanding act outcome } \\
\text { causation }\end{array}$ & $\begin{array}{l}\text { Verbal explanation of a rational } \\
\text { inference }\end{array}$ \\
\hline & $\begin{array}{c}\text { Implicit } \\
\text { Dimension }\end{array}$ & $\begin{array}{c}\text { Associative } \\
\text { Stimulus - Stimulus } \\
\text { Stimulus - Response } \\
\text { Response - Reinforcement }\end{array}$ & $\begin{array}{l}\text { Pavlovian condicioned response } \\
\text { Instrumental response reinforcement }\end{array}$ \\
\hline
\end{tabular}

Figure 2. Explicit and implicit psychological components of reward involving motivation, affect and learning dimensions. Adapted from Robinson and Berridge (2003)

2013). Rats self-administer playback vocalizations of 50$\mathrm{kHz}$ and avoid playback vocalizations of $22 \mathrm{kHz}$ (Burgdorf et al., 2008). Parsana et al. (2012) showed that ultrasonic vocalizations of $50 \mathrm{kHz}$ lead to activation of the amygdala whereas ultrasonic vocalizations of $22 \mathrm{kHz}$ lead to deactivation of the amygdala.

Panksepp (2011b) postulates seven primary process emotional networks, situated in subcortical regions of the brain - seeking, rage, fear, lust, care, grief and play - that can serve as emotional endophenotypes ${ }^{6}$ for psychopathological problems. Through electrical stimulation in old subcortical regions of the brain (ESB), powerful emotional unconditioned responses can be elicited in animals. Experimentally, giving opportunity for self-stimulation, it is possible to show that the animals "like" or "dislike" the ESB that evokes unconditioned instinctual emotional behaviors.

Neuroanatomically, all primal systems are situated subcortically, and consist of large transverse networks that interconnect midbrain circuits concentrated in midbrain regions, such as the PAG and ventral tegmental area (VTA), with various basal ganglia nuclei, such as amygdala and nucleus accumbens as well as cingulate and medial frontal

6 Endophenotypes are neuroanatomical, neurophysiological, neurochemical, emotional, motivational, cognitive or simple response tendencies. cortex, via pathways that run through the lateral and medial hypothalamus and medial thalamus. Each system has abundant descending and ascending components that work together in a coordinated fashion to generate various instinctual emotional behaviors, as well as the raw feelings normally associated with those behaviors. The raw affects engendered by these systems are ancestral memories (instincts) that promote survival - they anticipate the kinds of survival needs that all organisms require to successfully navigate the world. They also help mediate the poorly understood brain processes called "reinforcement" in traditional behavioristic learning theory, based upon the temporal association of external stimuli with the unconditioned affective responses of the nervous system. (p. 1797-1798)

\section{Conclusions}

What might we gain by accepting the invitation of Jaak Panksepp to leave the predominant position of denial of affective states in animals and to adopt a position that attributes the experience of these states to them?

There is now a solid observational database to draw the inference of affective states in animals. Researchers such as Jane Goodall (1990, 2000), Marc Bekoff (2000, 2002, 2007, 2009) and Cynthia Moss (2000), based on 
decades of experience studying the behavior of chimpanzees, canines and elephants, respectively, have no doubt in asserting that animals have rich emotional lives, agreeing with Jaak Panksepp. In his chapter "Animal emotions and animal sentience and why they matter: blending "science sense' with common sense, compassion and heart" published in the book Animals, Ethics and Trade, Marc Bekoff (2006) argues that with respect to the emotional lives of animals, the skeptics often use double standards and require more evidence than in other areas. Since affective experience is private, it is easy to say that you can never be sure that animals have emotions and to declare the case closed.

Nonetheless, a cursory glance at many studies in animal behavior, behavioral ecology, neurobiology and biomedicine shows clearly that only rarely do we ever come to know everything about the questions at hand, yet this does not stop us from making accurate predictions concerning what an individual is likely to do in a given situation or from suggesting the use of a wide variety of treatments to help alleviate different diseases. This is all in the patent absence of incontrovertible proof, in the absence of total certainty, something that few scientists can ever offer. (p. 34)

Consider the following examples on the double standard of proof: 1) At a symposium after Cynthia Moss presented her work on the behavior of elephants, including a wonderful video, a leader of the National Science Foundation asked "How do you know that these animals are feeling the emotions you claim they are?", and Cynthia replied "How you know they are not?"; 2) Ray Dolan (2002) published the article "Emotion, cognition, and behavior" in the prestigious journal Science. He is a neuroscientist, coordinates a Center of Neuroimaging, and studies the influence of emotion on decision making by humans. In his article, he concludes "More than any other species, we are beneficiaries and victims of a wealth of emotional experience." (p. 1191). We could ask Ray Dolan: "How do you know?" It is possible that other animals experience more vivid emotions than us. Why are we so special, why do we feel so deeply and other animals do not? We are led to think about speciesism, a term coined by psychologist Richard D. Ryder in 1970, which refers to the discrimination commonly practiced by man against other species and ignoring or underestimating the similarities between the discriminator and those discriminated against (Ryder, 1989, 2004).

The theory of Affective Neuroscience of Jaak Panksepp is based on the premise that animals have affective feelings, and this capability makes animal models so important for neuroscience to advance its understanding of the neural basis of human emotions. He proposes an innovative research agenda, which was not yet absorbed into the mainstream of neuroscience, inviting for an increased dialogue among psychoethologists, behavior analysts and neuroscientists, an increased activity of Laboratories of Animal Behavior, with the development and improvement of behavioral indices and theoretical models. Difficulties in communication between scientists exist, as illustrated by the episode of the FN, but occasional problems can be overcome in a collective perspective.

I would dare to paraphrase Kent Berridge (2004) and say that

Emotion $^{7}$ concepts are needed to understand the brain, just as brain concepts are needed to understand emotion. Emotion concepts can aid behavioral neuroscience to live up to its potential of providing brain-based explanations of emotional behavior in real life. Without them, neuroscience models would remain oversimplified fragments, removed from the behavioral reality they purport to explain. (p. 205)

I mention as a Brazilian example of the research agenda of Affective Neuroscience a study of Newton Canteras, my colleague of the Institute of Biomedical Sciences, University of São Paulo (Gross \& Canteras, 2012), recently published in Nature Reviews Neuroscience. He told me that he had scientific conversations about fear with Cesar Ades. This study illustrates how a basic animal research can offer insights to improve our understanding of fear and anxiety in humans, expanding the traditional view of fear derived from animal studies that use conditioning to discrete painful cues to encompass a wider range of ethological responses to fear stimuli. The study showed that fear of pain (footshock), fear of predators (cat/cat's smell) and fear of aggressive conspecifics in rats are processed in three independent neural pathways that include subnuclei of the amygdala, hypothalamus and periaqueductal gray (PAG ). It is possible to intervene specifically in each of these circuits. For example, rats with lesions in the fear of predator circuit do not show fear of cats or the smell of cats. Lesions of the pain circuit prevent the expression of conditioned fear of feetshock but do not interfere with the expression of fear of a predator. There is a notable anatomical preservation of the amygdala, hypothalamus and medial periaqueductal gray matter (PAG) involved in the processing of fear, suggesting that similar circuits for different classes of fear exist in other mammals, including humans. Knowing the fear circuit predominantly affected could help to develop psychotherapeutic and pharmacological interventions which will be more specific than interventions based on theoretical views that conceptualize fear as a unitary psychological construct. In humans, there is evidence that electrical stimulation of the dorsal part of the ventromedial nucleus of the hypothalamus (dmVMH) elicits a sensation of panic and impending death (Wilent, 2010) and that stimulation of the dorsolateral PAG causes a feeling of uncertainty and being chased by someone (Amano et al., 1982). Perhaps underlying panic attacks, which cause so much suffering to many people, is a circuit of predator fear.

7 Emotion was used in the place of motivation. 
In my point of view, Jaak Panksepp's Affective Neuroscience is different from what is done both in neuroethology and in behavioral neuroscience, in spite of overlapping areas of interest.

Neuroethology is a specialty which aims to understand the neural basis of the natural behavior of animal species. Research in this area began in the late 1960s and early 1970s. The International Society for Neuroethology (ISN) was created in Germany in $1981^{8}$. Behavioral neuroscience studies the brain systems underlying normal and abnormal human behavior, and use non-human animals models. The International Behavioral Neuroscience Society (IBNS) was founded in 1992 in the USA9 ${ }^{9}$. In Brazil, neuroethologists are members of the Brazilian Society of Ethology (SBEt) and behavioral neuroscientists are members of the Brazilian Society for Neuroscience and Behavior (SBNeC).

The Affective Neuroscience (AN), created by Panksepp in 1992, is the study of the neural mechanisms of emotion, with emphasis on the study of animal models to understand the basic human emotional systems and human affective disorders. AN considers that emotional feelings are closely related to instinctive animal processes. The objective is to study the primary process feelings and brain mechanisms in animals aiming at understanding basic human psychological processes.

Through an understanding of these primary-process systems, we may eventually be able to craft a scientifically sound general definition of emotions. These systems sustain their integrity in decorticated animals (Merker, 2007; Panksepp et al., 1994), but they probably control and are controlled by various higher brain processes that are hard to analyze psychologically in animal models, just like the lower subcortical systems are almost impossible to study, ethically, in any detail in humans. There is so much functional work left to be done on these systems, especially with regard to preclinical modeling of emotional distress, but relatively little is being conducted. This could be deemed regrettable because a cogent argument is readily made for the likelihood that these systems are of critical importance for all psychiatric disorders characterized by affective turmoil (Panksepp, 2006). Indeed, by taking these affective systems seriously, we may be heading toward more precise animal models of psychiatric disorders. (Panksepp, 2011b, p. 1798)

According to Panksepp (2010, 2011a,b, 2012), the primary process affective mind arose earlier in evolution than our sophisticated cognitive minds, and mammals share this basic process involving sensory, homeostatic

8 Interested readers can access the topics that are being discussed in ISN's meetings on the site http://psfebus.allenpress.com/eBusISNE/ HOME.aspx

9 The interested reader can access the topics that are being discussed in the meetings of IBNS on the site http://www.ibnsconnect.org/. and emotional affects (Table 1). Emotional feelings (affects) and subcortical regions of the brain underlying them, which are anatomically, neurochemically and functionally similar in all mammals studied, inform how organisms are performing with regard to important survival tasks. Primary process intensely experienced emotional feelings constitute the basis for secondary processes learning and memory mechanisms, and for tertiary processes involving higher order cognitive functions of the Mind/Brain.

The basic survival tool kit, with which nature presents organisms, is refined by basic learning mechanisms (secondary processes) and cognitions/higher-order thinking. The upward arrows in Table 1 indicate "bottom up" influences, and descendant arrows, "top down" regulations. The primary processes have a significant influence on the learning mechanisms (i.e., the development of Pavlovian conditioned responses and instrumental conditioned responses) and motivate superior decision-making processes. In this perspective, the cognitive apparatus is subservient to the emotional feelings often without realizing this subservience.

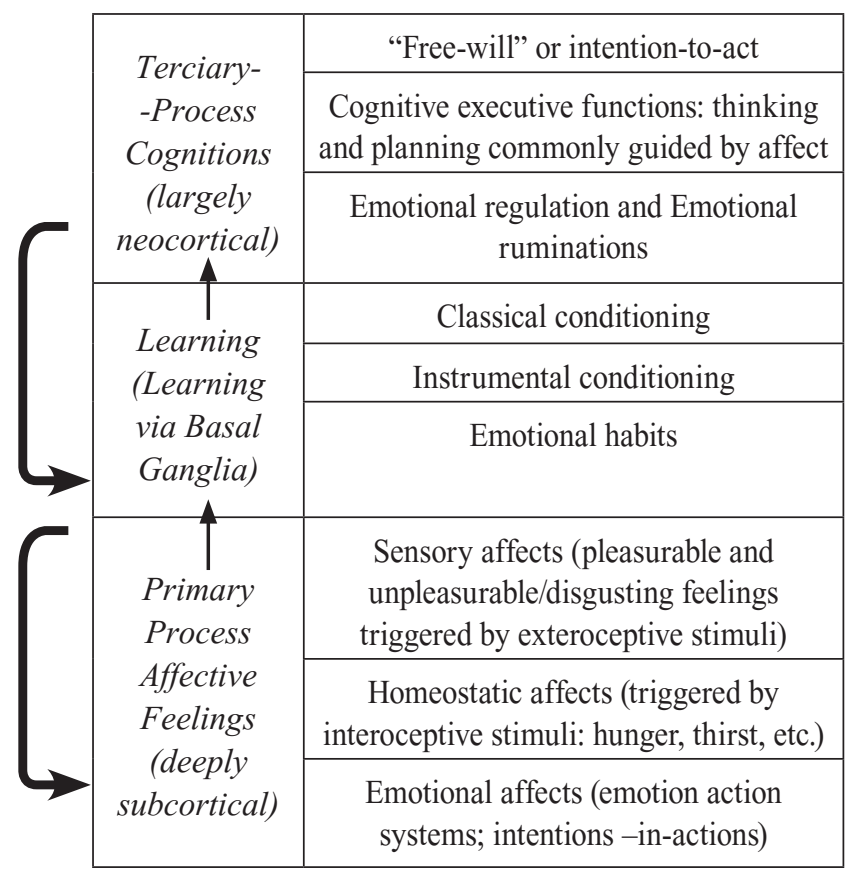

Figure 3. Operation of the mind/brain with embedded layers of "bottom up", and "top down" regulation. Adapted from Pankesepp $(2011,2012)$

At birth, the neocortex is largely a tabula rasa, and its functions are programmed into equipotential tissues, which initially resemble RAM (Random Access Memory). But after learning how to regulate affect (e.g., from finding food when hungry to control impulsivity when angry), higher mental processes arise and are gradually transformed into Programmable Read Only Memories (PROMs). From this perspective, the emphasis shifts from "I think, therefore I am" to "I feel therefore I think". 
Within such a view, many of the presuppositions of psychology, cognitive science, and neuroscience may be turned on their collective heads. Many of our higher mental abilities are comparatively unconscious, meaning unexperienced, for instance, key aspects of cognitive brain functions such as the basic mechanisms of learning and memory. In contrast, the affective foundations are intensely experienced - since they can serve as 'rewards' and 'punishments' in learning - albeit those psychological states are, at times, hard to translate into words, symbols which more effectively describe external sensory-perceptual abilities than emotional ones ... Without a solid cross-species neuroscientific foundation, it may be difficult to make sense of the subsequent mental developments of our species - e.g., the way our cognitive apparatus is often subservient to our emotional feelings. This is inherent in the nested hierarchical view of brain function. (Panksepp, 2011)

There is a notable lack of studies on primary processes, since human psychological research focused on the study of executive cognitive functions or learning (classical and instrumental conditioning). Understanding affective tools for life and learning that they exist at the level of primary processes, we can better comprehend how the higher mental processes operate (Oliva et al., 2006).

I hope the readers will feel encouraged to continue the discussion of the issues raised in this paper written because of a Footnote. If the scientific debate is prolonged, it can proceed without demerit as an 'Idle talk'.

\section{Reflexões a partir de uma nota de rodapé: implicações para o estudo de emoções em animais}

Resumo: Uma nota de rodapé (NR), originalmente submetida como um comentário ao artigo "Parsing Reward", me levou a escrever este ensaio. $O$ comentário foi rejeitado pelo editor de um renomado periódico científico na área de neurociências com a sugestão de que seria mais apropriado para uma "conversa de bar". Acredito que as questões essenciais envolvidas sejam significativas para um debate na área de fronteira das ciências humanas e biológicas. Os protagonistas envolvidos no didático episódio da NR, cujos artigos e livros tenho acompanhado nos últimos anos, são lideranças na área de neurociências. Neste ensaio contextualizo o episódio historicamente e o discuto em termos de perspectivas potenciais para a etologia, a psicologia e a neurociência.

Palavras-chave: emoção, animais, etologia, psicologia, neurociência.

\section{Réflexions sur une note de bas de page: implications pour leétude des emotions chez les animaux}

Résumé: Une note de bas de page (NBP) initialement soumise comme un commentaire de l'article «Parsing reward» m'a amenée à écrire cet essai. Ce commentaire fut rejeté par l'éditeur d'un prestigieux journal scientifique dans le domaine des neurosciences comportementales avec la suggestion qu'il serait plus approprié à une «discussion de comptoir». Je pense que les questions essentielles abordées dans cette note sont cruciales pour un débat sur la frontière entre sciences humaines et biologiques. Les protagonistes impliqués dans cet incident didactique, dont j'ai suivi les publications et les livres au fil des années, sont des leaders dans le domaine des neurosciences. Dans cet essai, après l'avoir remise dans son contexte historique, je discute les potentiels apports de cette note aux domaines de l'éthologie, de la psychologie et des neurosciences.

Mots-clés: émotion, animaux, éthologie, psychologie, neurosciences.

\section{Reflexiones a partir de una nota a pie de página: implicaciones para el estudio de las emociones en animales}

Resumen: Una nota a pie de página, presentada originalmente cómo un comentario al artículo "Parsing Reward", me llevó a escribir este ensayo. El comentario fue rechazado por un editor de un renombrado periódico científico en el área de las neurociencias, con la sugerencia de que sería más apropiado para una "conversación de bar". Creo que las cuestiones esenciales envueltas son significativas para un debate en la zona fronteriza de las ciencias humanas y biológicas. Los protagonistas envueltos en el didáctico episodio de la nota, cuyos artículos y libros he seguido en los últimos años, son líderes en el área de las neurociencias. En este ensayo contextualizo el episodio históricamente y lo discuto en términos de potenciales perspectivas para la etología, la psicología y la neurociencia.

Palabras clave: emoción, animales, etología, psicología, neurociencia. 


\section{Referências}

Amano, K., Tanikawa, T., Kawamura, H., Iseki, H., Notani, M., Kawabatake, H., ... Kitamura, K. (1982). Endorphins and pain relief. Stereotactic and Functional Neurosurgery, 45, 123-135.

Beach, F. A. (1950). The snark was a boojum. American Psychologist, 5, 115.

Bekoff, M. (2000). Animal Emotions: Exploring Passionate Natures Current interdisciplinary research provides compelling evidence that many animals experience such emotions as joy, fear, love, despair, and grief - we are not alone. BioScience, 50, 861-870.

Bekoff, M. (2002). Minding animals: awareness, emotions, and heart. New York, NY: Oxford University Press.

Bekoff, M. (2006). Animal emotions and animal sentience and why they matter: blending "science sense" with common sense, compassion and heart. In M. Bekoff (Ed.), Animals, Ethics and Trade (pp. 27-40). London, UK: Earthscan.

Bekoff, M. (2007). The emotional lives of animals: a leading scientist explores animal joy, sorrow, and empathy and why they matter. Novato, CA: New World Library.

Bekoff. M., \& Pierce, J. (2009). Wild justice: the moral lives of animals. Chicago, IL: University of Chicago Press.

Berridge, K. C. (2004). Motivation concepts in behavioral neuroscience. Physiology \& Behavior, 81, 179-209.

Berridge, K. C., \& Kringelbach, M. L. (2010). Pleasures of the brain. New York, NY: Oxford University Press.

Berridge, K. C., \& Kringelbach, M. L. (2011). Building a neuroscience of pleasure and well-being. Psychology of Well-Being, 1, 1-26.

Berridge, K. C., \& Kringelbach, M. L. (2013). Neuroscience of affect: brain mechanisms of pleasure and displeasure. Current Opinion in Neurobiology, 23, 294-303.

Berridge, K. C., \& Robinson, T. E. (2003). Parsing reward. Trends in Neurosciences, 9, 507-513.

Blanchard, R. J., Blanchard, D. C., Agullana, R., \& Weiss, S. M. (1991). Twenty-two kHz alarm cries to presentation of a predator, by laboratory rats living in visible burrow systems. Physiology and Behavior, 50, 967-972.

Breland, K., \& Breland, M. (1961) The misbehaviour of organisms. American Psychologist, 16, 681-684.

Brudzynski, S. M, \& Pniak, A. (2002). Social contacts and production of $50-\mathrm{kHz}$ short ultra-sonic calls in adult rats. Journal of Comparative Psychology, 116, 73-82.

Brudzynski, S. M. (2013). Ethotransmission: communication of emotional states through ultrasonic vocalization in rats. Current opinion in neurobiology, 23, 310-317.

Burgdorf, J., Knutson, B., \& Panksepp J. (2000). Anticipation of rewarding electricalbrain stimulation evokes ultrasonic vocalization in rats. Behavioral Neuroscience, 114, 320-327.

Burgdorf, J., Knutson, B., Panksepp, J., \& Ikemoto, S. (2001). Nucleus accumbens amphetamine microinjections unconditionally elicit $50-\mathrm{kHz}$ ultrasonic vocalizations in rats. Behavioral Neuroscience, 115, 940-944.
Burgdorf, J., Kroes, R. A., Moskal, J. R., Pfaus, J. G., Brudzynski, S. M., \& Panksepp, J. (2008). Ultrasonic vocalizations of rats (Rattus norvegicus) during mating, play, and aggression: behavioral concomitants, relationship to reward, and self-administration of playback. Journal of Comparative Psychology, 122, 357-367.

Choi, J. S., \& Brown, T. H. (2003). Central amygdala lesions block ultrasonic vocalization and freezing as conditional but not unconditional responses. Journal of Neuroscience, 23, 8713-8721.

Covington, H. E. III, \& Miczek, K. A. (2003). Vocalizations during withdrawal from opiates and cocaine: possible expressions of affective distress. European Journal of Pharmacology, 467, 1-13.

Cunha, W. H. de Andrade. (2004). On the panic reactions of ants to a crushed conspecific: a contribution to a psychoethology of fear. Revista de Etologia, 6, 133-140.

Darwin, C. (2000). A expressão das emoções no homem e nos animais. São Paulo, SP: Companhia das Letras. (Originally published in 1872).

Dolan, R. J. (2002). Emotion, cognition, and behavior. Science, 298(5596), 1191-1194.

Goodall, J. (1990). Through a window: 30 years observing the Gombe chimpanzees. London, UK: Weidenfeld \& Nicolson.

Goodall, J. (2000). 40 Years at Gombe. New York, NY: Stewart, Tabori, and Chang.

Gross, C. T., \& Canteras, N. S. (2012). The many paths to fear. Nature Reviews Neuroscience, 13, 651-658.

Knutson, B., Burgdorf, J., \& Panksepp, J. (1998). Anticipation of play elicits high-frequency ultrasonic vocalizations in young rats. Journal of Comparative Psychology, 112, 65-73.

Knutson, B., Burgdorf, J., \& Panksepp, J. (2002). Ultrasonic vocalizations as indices of affective states in rats. Psychological Bulletin, 128, 961-977.

Lamb, R. J., Preston, K. L., Schindler, C. W., Meisch, R. A., Davis, F., Katz, J. L., ... Goldberg, S. R. (1991). The reinforcing and subjective effects of morphine in post-addicts: a dose-response study. The Journal of Pharmacology and Experimental Therapeutics, 259, 1165-1173.

Lee, H. J., Choi, J. S., Brown, T. H., \& Kim, J. J. (2001). Amygdalar NMDA receptors are critical for the expression of multiple conditioned fear responses. Journal of Neuroscience, 21, 4116-4124.

Ma, S. T., Maier, E. Y., Ahrens, A. M., Schallert, T., \& Duvauchelle, C. L. (2010). Repeated intravenous cocaine experience: development and escalation of predrug anticipatory $50-\mathrm{kHz}$ ultrasonic vocalizations in rats. Behavioural Brain Research, 212, 109-114.

Merker, B. (2007). Consciousness without a cerebral cortex: A challenge for neuroscience and medicine. Behavioral and Brain Sciences, 30, 63-81. 
Moss, C. J. (2000). Elephant memories: thirteen years in the life of an elephant family. Chicago, IL: University of Chicago Press.

Oliva, A. D., Otta, E., Ribeiro, F. L., Bussab, V. S. R., Lopes, F. D. A., Yamamoto, M. E., \& Moura, M. L. S. D. (2006). Razão, emoção e ação em cena: a mente humana sob um olhar evolucionista. Psicologia: teoria e pesquisa, 22, 53-62.

Panksepp, J. (1990). Can "mind" and behavior be understood without understanding the brain?: A response to Bunge. New Ideas in Psychology, 8, 139-149.

Panksepp J (1992). A critical role for "Affective Neuroscience" in resolving what is basic about basic emotions. Psychological Review, 99, 554-560.

Panksepp, J., Normansell, L., Cox, J. F., \& Siviy, S. M. (1994). Effects of neonatal decortication on the social play of juvenile rats. Physiology \& Behavior, 56, 429443.

Panksepp, J. (1998). Affective neuroscience: the foundations of human and animal emotions. New York, NY: Oxford University Press.

Panksepp J (Ed.) (2004) A Textbook of Biological Psychiatry. New York, NY: Wiley.

Panksepp, J. (2005). Affective consciousness: Core emotional feelings in animals and humans. Consciousness and cognition, 14, 30-80

Panksepp, J. (2006). Emotional endophenotypes in evolutionary psychiatry. Biological Psychiatry, 30, 774784.

Panksepp J (2010) Affective consciousness in animals: perspectives on dimensional and primary process emotion approaches. Proceedings of the Royal Society $B, 277,2905-2907$.

Panksepp, J. (2011a). Cross-species affective neuroscience decoding of the primal affective experiences of humans and related animals. PLoS One, 6(9), e21236.

Panksepp, J. (2011b). The basic emotional circuits of mammalian brains: Do animals have affective lives? Neuroscience and Biobehavioral Reviews, 35(2011), 1791-1804.

Panksepp, J. (2012). A Synopsis of Affective Neuroscience - Naturalizing the Mammalian Mind. Journal of Consciousness Studies, 19, 4, 6-48.

Panksepp, J., \& Biven, L. (2012). The Archaeology of Mind: Neuroevolutionary Origins of Human Emotions (Norton
Series on Interpersonal Neurobiology). New York, NY: WW Norton \& Company.

Parsana, A. J., Li, N., \& Brown, T. H. (2012). Positive and negative ultrasonic social signals elicit opposing firing patterns in rat amygdala. Behavioural Brain Research, 226, 77-86.

Ribeiro, F. J. L. (2013). A originalidade de Walter Hugo de Andrade Cunha: geração espontânea. In E. Otta, F. J. L. Ribeiro, \& V. S. R. Bussab (Eds.), Lições da Alameda Glete: Coletânea de de textos de Walter Hugo de Andrade Cunha, pioneiro da etologia no Brasil. São Paulo, SP: IPUSP, 2013, pp. 181-197.

Ryder, R D (1989) Animal Revolution: Changing Attitudes towards Speciesism. Oxford, UK: Blackwell.

Ryder, R. D. (2004). Speciesism revisited. Think, 2, 83-92.

Skinner, B. F. (1953). Science and human behavior. New York, NY: Macmillan.

Thomas, D. A., Takahashi, L. K., \& Barfield, R. J. (1983). Analysis of ultrasonic vocalizations emit-ted by intruders during aggressive encounters among rats (Rattus norvegicus). Journal of Comparative Psychology, 97, 201-206.

Thompson, B., Leonard, K. C., \& Brudzynski, S. B. (2006) Amphetamine-induced $50 \mathrm{kHz}$ calls from rat nucleus accumbens: a quantitative mapping study and acoustic analysis. Behavioural Brain Research, 168, 64-73.

Tornatzky, W., \& Miezek, K. A. (1994). Behavioral and autonomic responses to intermittent social stress: differential protection by clonidine and metoporol. Psychopharmacology, 116, 346-356.

Vivian, J. A., Farrell, W. J., Sapperstein, S. B., \& Miczek, K. A. (1994). Diazepam withdrawal: effects of diazepam and gepirone on acoustic startle-induced $22 \mathrm{kHz}$ ultrasonic vocalizations. Psychopharmacology, 114, 101-108.

von Holst, E., \& Saint Paul, U. V. (1963). On the functional organization of drives. Animal Behaviour, 11, 1-20.

Wilent, W. B., Oh, M. Y., Buetefisch, C. M., Bailes, J. E., Cantella, D., Angle, C., \& Whiting, D. M. (2010). Induction of panic attack by stimulation of the ventromedial hypothalamus: Case report. Journal of Neurosurgery, 112, 1295-1298.
Recebido: $13 / 08 / 2014$

Revisado: 21/12/2014

Aceito: 10/01/2015 